were never responded to but at the time I complimented Sights Management on their erection of multilingual 'No feeding' signs at Apes' Den in October/November 1992.

I am disheartened that Sights Management has chosen to react so antagonistically to my article and it is sad that relevant information obtained within the last 2 years and offered to them free of charge was ignored. I intend to send Sight Management copies of my full report in the hope that some of the information may be useful.

We all recognize the problems at Apes' Den and the complexity of strategies it may take to resolve them. I have always encouraged and welcomed any positive steps taken on Gibraltar to improve macaque status and health and I would welcome hearing of further measures being taken because much still remains to be done.

Helen O'Leary
clo The Old Rectory, Petworth
West Sussex GU28 ODB, UK

\section{Rhinos in Kenya}

Having consulted Peter Jenkins I wish to comment on W. F. H. Ansell's remarks in 'Lake Nakuru Black Rhinoceros Sanctuary' (Oryx, 26 $[4], 236)$. There are doubts as to whether there are two subspecies of white rhino; it appears to be accepted by genetic experts that the difference between the northern and southern white rhinos is negligible. It is known that the white rhino occurred throughout East Africa in prehistoric times. White rhinos are being reintroduced successfully into many areas of Kenya from South Africa where there is a surplus due to successful conservation measures. Instead of being concerned over minute differences between subspecies, it might be more to the point if Kenya's example were followed and this surplus be introduced into more areas of East Africa rather than being shot by trophy hunters.

When white rhinos are introduced into a fenced area, such as Lake Nakuru National Park, there is no danger of cross-breeding be- cause there are no resident animals to start with. The white rhino is a much higher profile animal for tourists, being more easily accessible than the black rhino for photography on the plains.

Mr Ansell writes that, 'it is misguided to expend what are no doubt limited resources on the southern form'; in this he is incorrect because there are no northern rhinos available for translocation and South Africa is delighted to provide southern animals for introduction.

With regard to Christopher Lever's letter (Oryx, 26 (4), 236), I wish to reply as follows.

1. Rhino Rescue Trust was formed in 1985 as a result of an invited after-dinner talk to the Shikar Club by Peter Jenkins, the architect of the Rhino Rescue Project of Kenya. The Trust funded the Lake Nakuru Sanctuary and its development and management plan suggested stocking with a founder population of black rhino and, should the opportunity arise, introducing white rhinos also because there was ideal habitat for them.

2. It is recognized that the Rhino Rescue Trust was started in order to help save the black rhino from extinction and, therefore, to fund sanctuaries. However, the Trust should recognize the value of the white rhino as good public relations and the spin-off will benefit the black rhino.

3. My only part in assisting with the Lake Nakuru Sanctuary was in the translocation of the black rhino from Solio. However, as warden of Solio Game Reserve for many years my 'assistance to Peter Jenkins's plan for rhino sanctuaries' was in an advisory capacity, having had experience of a ring-fenced situation and having been involved in capture and translocation.

I do feel that had it not been for Peter Jenkins's pressing for concrete measures to save the black rhino from extinction, conceiving the Special Sanctuary idea and the formation of the Rhino Rescue Trust, then there would have been no safe area for the excess rhino from Solio Reserve. Undoubtedly Kenya is indebted to the Rhino Rescue Trust for its part in saving the black rhino.

R.T. Elliott

PO Box 62, Gilgil, Kenya 